\title{
Effect of seaweed extracts on growth and yield of rice plants
}

\author{
SUNARPI", AHMAD JUPRI, RINA KURNIANINGSIH, NUR INDAH JULISANIAH, ALUH NIKMATULLAH \\ Biology Program, Faculty of Mathematics and Natural Sciences, University of Mataram, Mataram 83125, West Nusa Tenggara, Indonesia. Tel.: +62-370 \\ 633004; Fax.: +62-370 636041; `email: ekajp@yahoo.com
}

Manuscript received: 8 January 2010. Revision accepted: 19 July 2010.

\begin{abstract}
Sunarpi, Jupri A, Kurnianingsih R, Julisaniah NI, Nikmatullah A 2010. Effect of seaweed extracts on growth and yield of rice plants. Nusantara Bioscience 2: 73-77. Application of liquid seaweed fertilizers on some plant species has been reported to decrease application doses of nitrogen, phosphorus, and potassium on some crop plants, as well as stimulating growth and production of many plants. It has been reported that there are at least 59 species of seaweeds found in the coastal zone of West Nusa Tenggara Province, 15 of those species weres able to stimulate germination, growth, and production of some horticultural and legume plants. This research aims to investigate the effect of seaweed extracts obtained from ten species on growth and production of rice plants. To achive the goal, seaweed $(100 \mathrm{~g}$ per species) wasextracted with $100 \mathrm{~mL}$ of water, to obtain the concentration of $100 \%$. Seaweed extract $(15 \%)$ was sprayed into the rice plants during vegetative and generative stages. Subsequently, the growth and yield parameters of rice plants were measured. The results showed that extracts of Sargassum sp.1, Sargassum sp.2, Sargassum polycistum, Hydroclathrus sp., Turbinaria ornata, and Turbinaria murayana, were able to induce growth of rice plants. However, only the Hydroclathrus sp. extract could enhance both growth and production of rice plants.
\end{abstract}

Keywords: extract, seaweed, growth, production, rice plants.

\begin{abstract}
Abstrack Sunarpi, Jupri A, R Kurnianingsih, Julisaniah NI, Nikmatullah A. 2010. Pengaruh ekstrak rumput laut terhadap pertumbuhan dan produksi tanaman padi. Nusantara Bioscience 2: 73-77. Aplikasi pupuk cair rumput laut pada beberapa spesies tanaman, telah dilaporkan dapat menurunkan dosis aplikasi nitrogen, fosfor dan kalium pada berbagai tanaman pangan, serta merangsang pertumbuhan dan produksi tanaman. Telah dilaporkan bahwa terdapat paling sedikit 59 jenis rumput laut yang tumbuh di wilayah pesisir Provinsi Nusa Tenggara Barat, 15 jenis diantaranya dapat merangsang perkecambahan, pertumbuhan dan produksi tanaman hortikultura dan legum. Tujuan penelitian ini adalah untuk mengetahui pengaruh ekstrak 10 jenis rumput laut terhadap pertumbuhan dan produksi tanaman padi. Rumput laut, $100 \mathrm{~g}$ setiap jenis, diekstraksi dengan $100 \mathrm{~mL}$ air, untuk mendapatkan konsentrasi $100 \%$. Ekstrak rumput laut $(15 \%)$ disemprot ke tanaman padi selama tahap vegetatif dan generatif. Selanjutnya, parameter pertumbuhan dan hasil tanaman padi diukur. Hasil penelitian menunjukkan bahwa ekstrak Sargassum sp.1, Sargassum sp.2, Sargassum polycistum, Hydroclathrus sp., Turbinaria ornata, dan Turbinaria murayana, mampu menginduksi pertumbuhan tanaman padi. Namun, hanya ekstrak Hydroclathrus sp. yang dapat meningkatkan pertumbuhan dan produksi tanaman padi.
\end{abstract}

Kata kunci: ekstrak, rumput laut, pertumbuhan, produksi, tanaman padi.

\section{INTRODUCTION}

Nationwide, the need for nitrogen $(\mathrm{N})$, phosphorus $(\mathrm{P})$ and potassium $(\mathrm{K})$ fertilizers increased from 96,116 tons in 2006 to 739,271 tons in 2007 (Pusri 2008). The increase tends to be caused by the dosage increase of fertilizer used in per unit area. Facts show that farmers use about 300-350 $\mathrm{kg}$ of urea per hectare of rice, and about $200-250 \mathrm{~kg}$ per hectare to plant vegetables and fruits. This condition certainly not only increases production costs, but also reduces soil fertility, and causes environmental pollution. Ironically, the increase in fertilizer costs, coupled with a variety of economic losses due to excessive fertilization, is not followed by the increase in farmers' income.

In order to decrease the financial burden of the farmers, the government then has raised the fertilizer subsidy from 1.5 trillion in 2006 to around 5 trillion in 2007 (Agency for Agricultural Research and Development 2008). The provision of subsidy funds did not solve the problem of agricultural production. Instead, it causes the scarcity/lack of fertilizers in the country due to act of irresponsible speculators who selling the subsidized fertilizer to other countries. Therefore, the efforts to maximize the absorption of nutrients by spraying extracts of natural products that contain stimulants, is a strategic move to suppress the use of excessive doses of inorganic fertilizer.

Results of previous studies reported that some liquid fertilizer products made from raw seaweeds found in some countries, such as Seasol in Australia (Tay et al. 1987), Kelpak in Europe (Beckett and van Staden 1989), SM3, SM6 and Maxicrop in the United States (Hankins and Hockey 1990), Algaenzims in Mexico (Sanchez et al. 2003) and Algifert, Goemar GA14, Seaspray, Cytec and Seacorp in India (Sivasankari et al. 2006). They are proven to increase the absorption of nutrients, which can enhance growth, development, and production of various species of agricultural crops. 
West Nusa Tenggara (NTB) marine waters are reported to have about 59 species of seaweed (Sunarpi et al. 2005, 2006), 15 species of which can stimulate the germination of watermelon and sesame seeds (Sunarpi et al. 2007), the growth of bean plants (Sunarpi et al. 2008), the growth and production of tomato plants (Sunarpi et al. 2008; Sunarpi et al. 2008). In addition, Thangaraju (2008) succeeded in lowering the dose of urea fertilizer in rice plants by spraying seaweed extract to the plants. However, there is insufficient information on the effect of seaweed extract which grows in tropical waters on the growth and yield of rice. Given the aforementioned facts, the study aims to determine the effect of several types of seaweed extracts on growth and yield of rice. The results showed that the extract of seaweed Sargassum sp.1, Sargassum sp.2, Sargassum polycistum, Hydroclathrus sp., Turbinaria ornata, and Turbinaria murayana are able to induce vegetative growth of rice plants. However, only the extract of Hydroclathrus sp. that influences the growth and yield of rice. This has implications for efforts to reduce the dose of NPK fertilizer use, so it can lower the production costs and reduce environmental pollution on rice plants.

\section{MATERIALS AND METHODS}

\section{Design, time and place of study}

The study was designed using completely randomized design (CRD), which consists of treatment of ten kinds of seaweed extract, which is Turbinaria murayana, Turbinaria ornata, Sargassum sp.1, Sargassum sp.2, Sargassum polycistum, Ulva fasciata, Ulva ferticulata, Padina sp., Chaetomorpha sp., and Hydroclatrus sp. The study was conducted in July-November 2009. Samples were taken from several sampling points in the sea of Lombok Island. The seaweed extraction was performed at the Laboratory of Imunobiology, Faculty of Mathematics and Natural Sciences, Mataram University. Rice planting and treatment were done in plastic house at Jatisela Village, Gunung Sari Subdistrict, West Lombok District, West Nusa Tenggara.

\section{Preparation of seaweed extract}

Seaweed that has been collected on Lombok sea waters, i.e. Turbinaria murayana, Turbinaria ornata, Sargassum sp.1, Sargassum sp.2, Sargassum polycistum, Ulva fasciata, Ulva ferticulata, Padina sp., Chaetomorpha sp., and Hydroclatrus sp., eachwas weighed as much as 100 grams, cut into pieces and placed in the blender. After that, $100 \mathrm{~mL}$ of distilled water was added ( ratio of 1:1 (w/v)), the mixture then blended until smooth, and filtered using filter paper. The slurry was centrifuged for 5 minutes at $4^{\circ} \mathrm{C}$ at $5000 \mathrm{rpm}$ speed. Following this, the supernatant was transferred to a Falcon tube (designated as an extract with $100 \%$ concentration). Finally, $15 \%$ extract was prepared by mixing $15 \mathrm{~mL}$ of it into $85 \mathrm{~mL}$ of water.

\section{Planting and plant treatment}

The medium used in this study is potting mix composed of soil, sand, and manure (1:1:1 (w.w). The three components were then homogeneously mixed, weighed 8 pounds, and put in a plastic pot (size of $5 \mathrm{~L}$ ). Rice seeds were showed by spreading them in the nursery pots containing planting medium as described previously. After 21 days, rice seedlings were planted in the medium that had been prepared in the pot, one clump per pot. Inorganic fertilizers, NPK fertilizer each with a dose of $2.4 \mathrm{~g}$ urea, $1.2 \mathrm{~g} \mathrm{KCl}$ gTSP and 0:36 per pot, were applied to the pot 14 days after transplanting. During the course of experimentation, the plant was maintained e according to procedure standards for paddy crop, from planting to harvesting the rice crop.

Seaweed extract treatment was done by spraying the whole plant ( 4 times, 2 times during the vegetative phase and 2 times during the generative phase). Spraying on the vegetative growth phase was done when the rice was 3 weeks and 6 weeks after planting, with spray volume of 20 and $30 \mathrm{~mL}$ per pot. During the generative phase the spraying was carried out on the time of flowering and fruit filling, each spray volume was $50 \mathrm{~mL}$ per pot.

Growth parameters observed were plant height, number of leaves, number of tillers and weight of stems and roots. Plant heigh was observed by measuring the plant height from the base of the clump which was exactly above the ground until the end of the highest grove. Number of leaves was observed by counting the number of leaves on each clump, while number of tillers was observed by counting the number of puppies/tillers that grow from each clump. The observation was carried out from 14 days after planting, with intervals of 3 days. eight of stems and roots were measured after the completion of all other rs observation. Observations were conducted by calculating the fresh weight of plants.

The crop yield parameters observed were the number of panicles, number of grains (seeds), weight per 100 seeds, and weight of seed per clump/ The number of panicles was calculated by counting the number of panicles in each clump of plants per pot. Number of grains (seeds) per panicle was observed by calculating the number of grains (seeds) per panicle in each clump while weight per 100 seeds was observed by measuring the weight per 100 seeds. Weight of seeds per clump was observed measured by measuring the weight of seeds in each clump. All the data obtained are expressed in the form of an average of replications $\pm \mathrm{SE}$.

\section{Data analysis}

Data were analyzed only by calculating the average value of three replications in each test, and presented in graphical form.

\section{RESULTS AND DISCUSSION}

\section{Vegetative growth of rice}

The effect of several kinds of seaweed extracts on the growth and production of paddy was observed by measuring some growth and yield parameters of rice 
following the treatments. Growth parameters observed were plant height, leaf number, number of tillers, weight stems and roots.

Most of the seaweed extracts tested did not give positive response to the rice plant height. They mostly decreased the plant height while only the height of rice paddy treated with three extracts, Sargassum sp.1, Ulva ferticulata, and Hydroclathrus sp., were not suppressed. Interestingly, the height of plants treated with extract of Sargassum sp.1 $(91.67 \mathrm{~cm})$ was slightly higher than the control plants $(91.00 \mathrm{~cm})$ (Figure 1).

Different phenomena are found in the number of leaves. Most of the plants that were given seaweed extract treatments had 5-25 more leaves compared with control plants. The highest average number of leaves was observed in Sargassum sp.1- and S. polycistum-treated plants, at which 100.33 leaves were found compared to 75.7 leaves in control plants (Figure 2). The big difference in the number of leaves on the plant-treated with extracts and without the extract indicates the effect of seaweed extracts on the number of leaves of rice. This phenomenon may be due to the presence of active compounds, micro-and macronutrients in the extract of seaweeds (macroalgaes), which can stimulate plant growth (Abetz 1980; Finnie and Van Staden 1985). Previously, it was suggested that various species of marine algae found in nature or commercially cultivated contain organic compounds which activity resemble the activity of a cytokinin, auxin, and gibrellin (Crouch and Van Staden 1993). These compounds were able to stimulate growth as a result of enhancement of protein synthesis and cell division, and t mobilization of nutrients needing for growth (Pascale et al. 1993).

The seaweed extracts increase the number of tillers of rice plants (Figure 3). There were four kinds of seaweed extracts that able to induce the formation of rice plant tillers. The highest number of tillers present in planttreatedwith Hydroclathrus sp. (26.33 tillers), followed by Turbinaria ornata (25 new plants), while the average number of tillers on control plants was only about 18 .

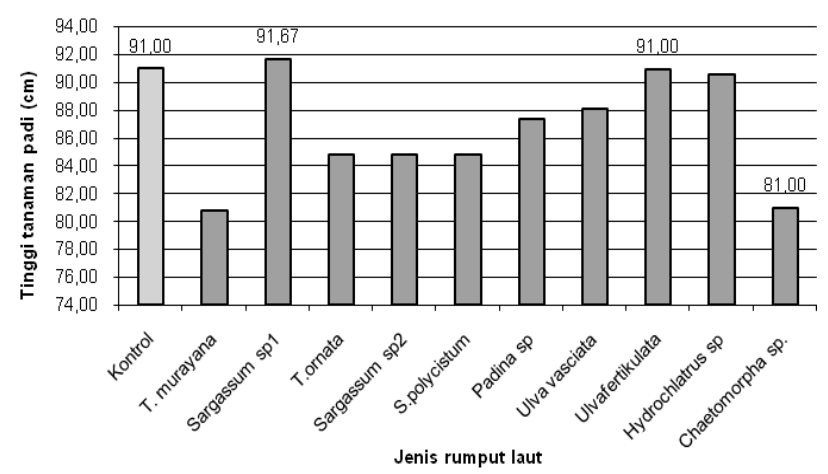

Figure 1. The effect of seaweed extract to the height of rice plants.

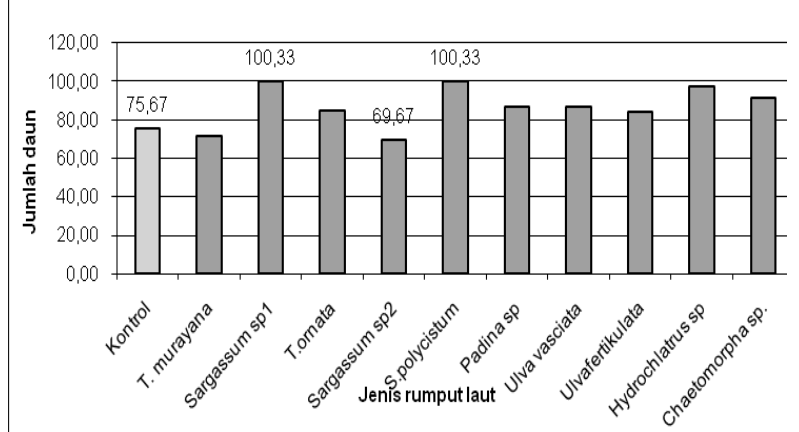

Figure 2. The effect of seaweed extracts on the number of leaves of rice plants.

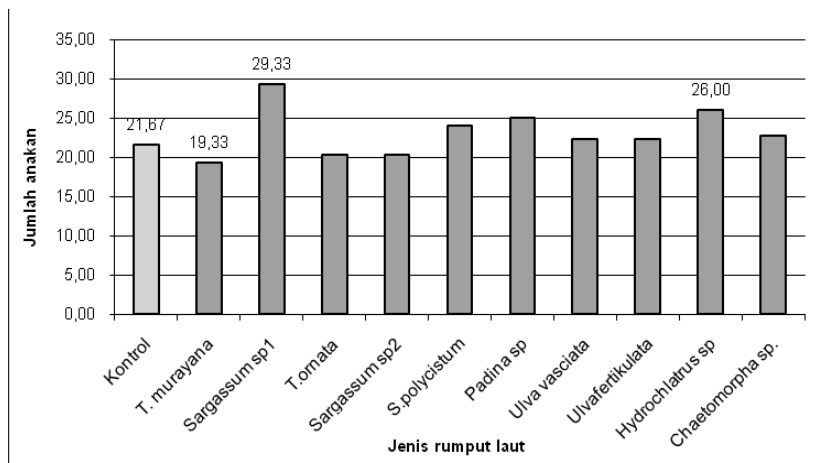

Figure 3. The effect of seaweed extracts on the number of tillers of rice plants

In regard to fresh weight of stems and roots, extracts Hydrocalthrus sp. has significantly enhanced the growth by increasing fresh weight of rice plant stems and roots (Figure 4). Hydrocalthrus sp.-treated plants have an average weight of $190.5 \mathrm{~g}$ ( the weight of control plant is only $130.87 \mathrm{~g}$ ) and roots fresh weight of $51 \mathrm{~g}$ (the weight of control plant is $39.3 \mathrm{~g}$ ).

Plant weight is affected by the concentration of nutrients, as well as the quantity of photosynthetic products of the plant. Seaweed extract application on plant is suggested to capable of increasing nutrient concentrations in the leaves, through involvement of growth hormone in the process of nutrients absorption and movements in a plant, thus increasing the weight of the plant. . It was reported in other systems that seaweed extract known of Ascophyllum nodosum contains growth hormones, namely IAA, while brown alga $S$. heterophyllum contains sitokinin (Crouch and Van Staden 1993). On addition, Smith and Van Staden (1984) found that cytokinin activity was higher in plants treated with seaweed extract compared to the control-untreated plants.

\section{Production of rice}

Effect of seaweed extract treatment on rice was also observed in the rice product. In this study, several yield parameters observed were the number of panicles, number of grains (seeds) in each panicle, and weight per 100 seeds. The number of panicles formed depends on the number of tillers present in every plant rice. The number of panicles 
that were formed will be directly proportional to the number of tillers came out in the rice plant. As explained previously that most types of seaweed extract give a quite positive influence on the growth of rice seedlings. In line with these conditions, the number of panicles on the planttreated with seaweed extracts were higher than the control plants (without extract). Plants that have the most number of panicles is a plant-treated with Hydroclathrus sp. extract with an average number of panicles of 26.33, while the control plants have only 18 units (Figure 5). Seaweed extract-treated plants were capable to produce more grain (seed) per penicle (Figure 6). Control plants were only capable of producing 160.11 grain per penicle, while the plants which were given Hydroclthrus sp. seaweed extract produced 171.11 grains per penicle. Although seaweed extracts enhanced the number of seeds per penicle, they did not alter grain weight. In most cases, they promoted similar 100-grain weight per penicle ot in other cases they even decreased it Figure 7).

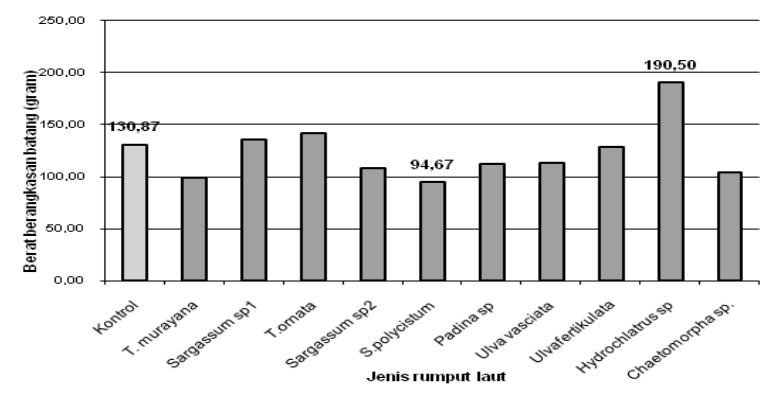

A

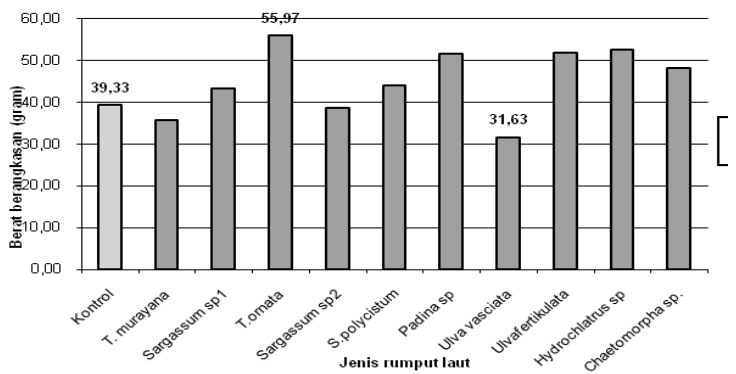

B

Figure 4. The effect of seaweed extract to the brangkasan weight of the rice plant: A. Roots, B. Stem.

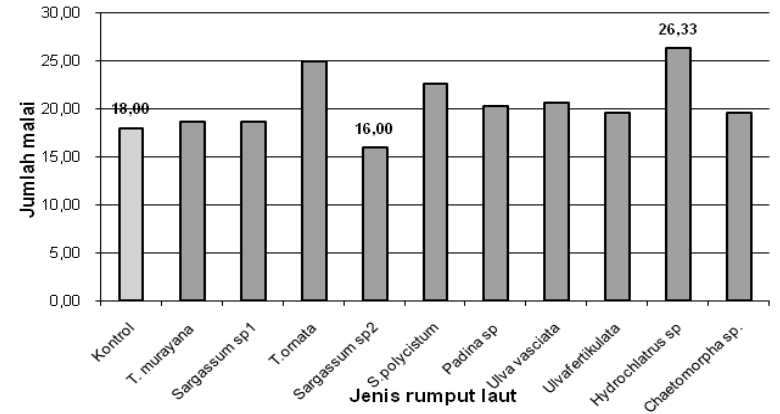

Figure 5. The effect of seaweed extract to the amount of rice panicle

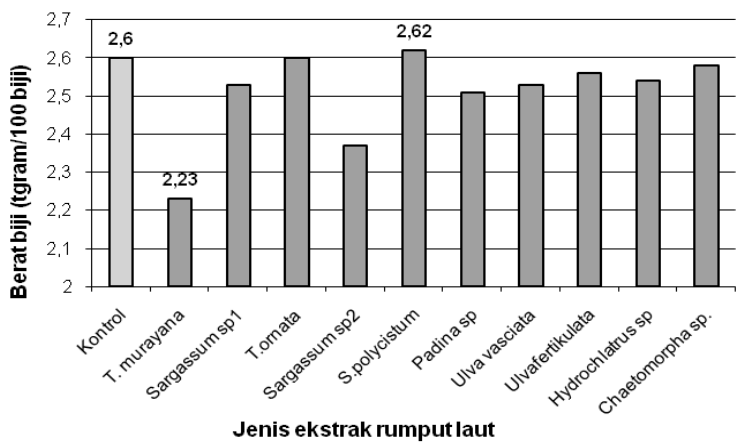

A

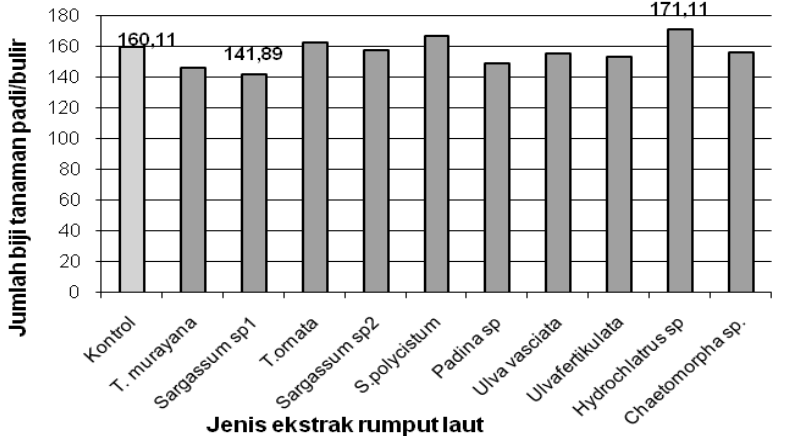

Figure 6. The effect of seaweed extract on number of grains (seeds) on each panicle rice plants

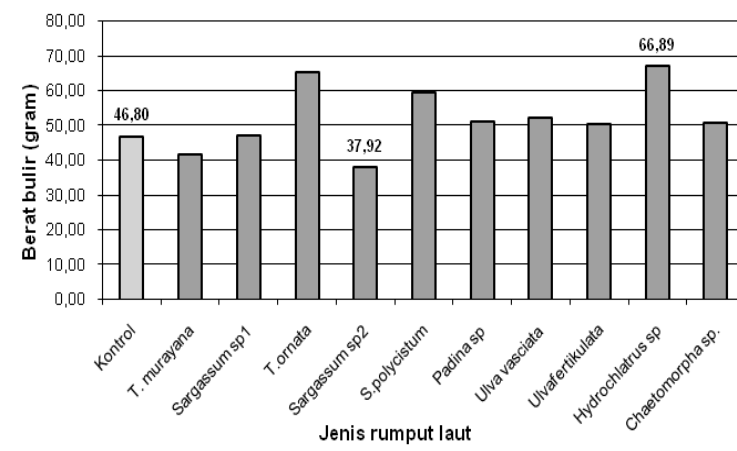

B

Figure 7. The effect of seaweed extracts on seed weight of rice plants; A. Weight per 100 seeds, B. Heavy seeds /clump. 
The opposite occurs on the weight of grain (seed) in each clump of rice plants. The highest grain weight in each cluster was observed in plant treated with extract Hydroclathrus sp. which is about $66.89 \mathrm{~g}$, while control plants weighed only about $46.80 \mathrm{~g}$ (Figure 7). Taken together, the results indicate that application of extracts from some seaweed species could promote growth and production of rice paddy and this implies that it may be possibility to reduce the inorganic fertilizers dosage for rice paddy cultivation.

\section{CONCLUSIONS AND RECOMMENDATIONS}

Seaweed extracts that are able to induce vegetative growth of rice plants are the extract of Sargassum sp.1, Sargassum sp.2, Sargassum polycistum, Hydroclathrus sp., Turbinaria ornata, and Turbinaria murayana. However, only extracts Hydroclathrus sp. that can stimulate both growth and yield of rice. Further studies are now underway to examine the effect of combined extracts and solid fractions of seaweed on growth and production of rice plants as well as to test the effect of seaweed solid and liquid fractions on NPK fertilizer use efficiency in rice cultivation.

\section{ACKNOWLEDGEMENTS}

The research team would like to thank DP2M Higher Education, Ministry of National Education, RI for allocated research grant in 2009 to support this research. We would also like to extend our thanks to the Chairman of the Research Institute of the University of Mataram $r$ for all administrative support enabling this research to be conducted. Thanks also go to the Dean of Faculty of Science, State University of Mataram which give us permission to use any facilities of Immunobiology Laboratory, so that this research can be conducted. Hopefully, all support is recorded as a charity that will get rewarded accordingly by God Almighty, Amen.

\section{REFERENCES}

Abetz P. 1980. Seaweed extract: have they a place in Australian agriculture or horticulture?. J Aust Inst Agric Sci 46: 23-29.

Agency for Agricultural Research and Development. 2008. Policy analysis of capital, land and water resources. www.litbang.deptan.go.id. [Indonesian]

Beckett RP, Van Staden J. 1989. The effect of seaweed concentrate on the growth and yield of potassium stressed wheat. Plant Soil 116: 29-36.

Crouch IJ, Van Staden J. 1993. Evidence of the presence of plant growth regulators in commercial seaweed product. Department of Botany, University of Natal, Durban, South Africa.

Finnie JF, Van Staden J. 1985. The effect of seaweed concentrate and applied hormones on in vitro cultured tomato roots. J Plant Physiol 120: $215-310$.

Hankins SD, Hockey HP. 1990. The effect of liquid seaweed extract from Ascophyllum nodosum (Fucales, Phaeophyta) on the two-spotted red spider mite Tetranychus urticae. Hydrobiologia 204/205: 555-559.

Pascale P, Claude J, Kloareg B, Lineart Y, Rochans C. 1993. Seaweed liquid fertilizer from Ascophyllum nodosum contains elicitor of plant d-glycanase. J Appl Phycol 5: 343-349.

Pusri. 2008. Data realization of production, consumption, export and import of fertilizer. www.APPI.or.id. [Indonesian]

Sanchez JAV, Ilyina A, Mendez-Jimenez LP, Robledo-Torres V, Rodriguez-Herrera R, Canales-Lopez B, Rodriguez-Martinez J. 2003. Isolation of microbial groups from a seaweed extract and comparison of their effect on growth of pepper culture (Capsicum annuum L.). Bect Mock 44: 92-96.

Sivasankari S, Venkatesalu V, Anantharaj M, Chandrasekaran M. 2006. Effect of seaweed extract on the growth and biochemical constituents of Vigna sinensis. Biores Technol 97: 1745-1751.

Sunarpi, Jupri A, Suripto, Rusman, Suastika IBM. 2005. Seaweed species diversity in West Nusa Tenggara. [Research Report]. Balai Budidaya Laut Lombok, Mataram. [Indonesian]

Sunarpi, Jupri A, Nurahman. 2007. Screening of West Nusa Tenggara seaweed that potential as raw materials of organic fertilizer. [Research Report]. Faculty of Mathematics and Natural Sciences, University of Mataram, Mataram. [Indonesian]

Sunarpi, Jupri A, Nurahman. 2008. Test of concentration and time giving extract of some seaweed species on the growth and production of tomato. [Research Report]. Faculty of Mathematics and Natural Sciences, University of Mataram, Mataram. [Indonesian]

Smith BC, Van Staden J. 1984. The effect of seaweed concentrate and fertilizer on growth and the endogenous cytokinin content of Phaseolus vulgaris. SA J Bot 3: 375.

Tay SAB, Palni LMS, MacLeod JK. 1987. Identification of cytokinin in a seaweed extract. J Plant Growth Regul 5: 133-138.

Thangaraju N. 2008. Efficacy of seaweed liquid fertilizers (SLFs) of Sargassum wightii Grev. and Ulva lactuca on the growth and yield of paddy (Oryza sativa L. var ADT 36) under greenhouse conditions. Proceeding of The $11^{\text {th }}$ International Conference on Applied Phycology. Galway-Ireland, 21-27 June 2008. 